\title{
Comparison of Ukraine and the EU on Key Indicators of a Healthy Economy
}

\author{
LIUDMYLA Yu. SAHER ${ }^{i}$, NatALIIA Ye. LetunOVSKa ${ }^{i i}$, \\ ANASTASIA P. NAZARENKO
}

\begin{abstract}
Modern approaches to economic management are based on sustainable development principles, which ensure the balance between economic, environmental, and social targets of public policy, balancing society's current and future interests. The mechanism for achieving the target values of sustainable development indicators is the formation of a healthy economy. A healthy economy provides opportunities for stable growth and minimizes social risks caused by economic problems.

The importance of forming a healthy economy is confirmed by a significant amount of research on this topic in developed countries, particularly the European Union. The Ukrainian scientific community ignores this issue. That indicates different economic management approaches, identifying priorities for its development, coordinating economic and social, strategic, and tactical goals.

The paper presents a comparative analysis of key indicators that determine a healthy economy. Such indicators include GDP, employment, and inflation. According to numerous studies, these indicators are the most indicative in assessing the economic system to determine whether it can be considered healthy. As a result of the study, significant differences in Ukraine and the European Union's studied indicators were revealed. Based on statistical information, a steady upward trend in key indicators of socioeconomic development in the European Union has been established. Instead, similar indicators in Ukraine indicate economic instability, which has a significant negative impact on the country's further development and the prospects for a healthy economy. Thus, the analysis allows us to conclude that the European Union's economy generally meets the definition of a healthy economy and creates the conditions for sustainable development of the European Union. Instead, Ukraine's economy is focused on solving tactical problems and cannot solve socio-economic development's strategic tasks.
\end{abstract}

Keywords: healthy economy, comparative analysis, development indicators, GDP, employment, inflation, European Union

УДК: 330.3:339

JEL Codes: E00, O10, 057

Introduction. Increased economic activity, in most cases, implies an increase in the consumption of energy and other natural resources, as well as emissions and production waste. At the same time, economic growth creates opportunities to finance environmental measures by introducing cleaner and less resource-intensive technologies and the production of environmentally friendly products. The priority of both directions (recognition of economic and social needs, and at the same time understanding of constraints) involves following the concept of sustainable economic development. The main task of sustainable development is to ensure dynamic socio-economic growth, preserve the environment, and rational use natural resources to meet the needs of the population by building a highly efficient economic system that stimulates productive labor, scientific and technological progress, and has a social focus.

${ }^{i}$ Liudmyla Yu. Saher, C.Sc. (Economics), Associate Professor, Department of Marketing, Sumy State University;

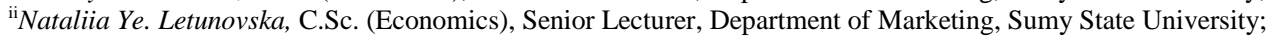

${ }^{i i i}$ Anastacia P. Nazarenko, Student, Department of Marketing, Sumy State University.

(C) L. Yu. Saher, N. Ye. Letunovska, A. P. Nazarenko, 2020.

https://doi.org/10.21272/mer.2020.89.10 
The solution to this problem is facilitated by forming a healthy economy of a particular region or country.

Problem statement. Modern scientific and practical approaches to study of a healthy economy have been studied rather profoundly in the works of Holloway S. R., Marshall E., Mikhailitchenko A., Philp T., Šíma J., Tootelian D. H., Varshney S. B, Yanushevsky R., Yanushevsky $\mathrm{C}$. The following scientists deal with the analysis of the country's economy, its social and innovative components: Amadeo K., Bilan Y., Lyulyov O., Nagornyi Ye., Pimonenko T., Rybina O., Syhyda L., Vasilyeva T.

Mentioning significant scientific and practical achievements in the field of study, it should be noted that in Ukraine up to this time, the issues related to healthy economy and it's measurement have remained insufficiently elaborated and worked at.

The purpose of the article is to compare Ukraine and the EU on key indicators of a healthy economy.

\section{Results of the research.}

A healthy economy in a steady state has the following three conditions [9]:

1. Systemic strength: low concentration of wealth, low concentration of commerce (i.e., healthy competition).

2. Stable micro-economic conditions: consistent consumer prices, broad and recursive market participation (e.g., low unemployment).

3. Healthy macro-economic conditions: high liquidity in currency with low volatility.

It is vital to move to the formation of a healthy economy in Ukraine, which, with significant resource potential, is in a state of economic crisis and only one of the first stages of implementing the sustainable development goals. Given the geographical proximity, the signed association, and the legally defined strategic direction of Ukraine's movement in the EU, it is advisable to adopt European Union social and economic development standards.

Prolonged implementation of EU economic and social policy aimed at ensuring high living standards, harmonious combination of economic, social and environmental goals, as well as the development of mechanisms to support all economic actors in the implementation of certain sustainable development goals allowed to consider the EU as a successful model of a healthy economy, which substantiates the feasibility of analyzing the proximity of Ukraine's economy to the economy of EU countries on key indicators:

1. GPD.

2. Employment.

3. Price stability.

A comparison of the dynamics of changes in Ukraine and EU GDP allows us to identify certain patterns associated with the concept of a healthy economy. In particular, it is worth noting the steady growth trend of a critical macroeconomic indicator - GDP - in the EU in the period from 1995 to 2019. The decline in the EU GDP was observed in 2008 and was caused by the global economic crisis, but compared to Ukraine, the relative decline in GDP was lower. This steady trend of GDP change is in line with sustainable development goals, which provide balanced economic growth and the achievement of economic and social, and environmental goals, which are defined by the EU regulatory framework and formalized for sustainable development. At the same time, stable economic growth (confirmed by a critical macroeconomic indicator - GDP) and the background of abandoning the priority of economic goals and the principle of maximizing profitability indicates the current socio-economic model focused on ensuring high standards of quality of life. 
Unlike the EU, although Ukraine's GDP has a global upward trend, periods of growth alternate with economic downturns. It indicates that the prerequisites for sustainable economic development are not formed, and the economy tends to be affected by several factors that significantly affect macroeconomic indicators. In such a situation, it is difficult to ensure the achievement of strategic and tactical social and economic goals and adhere to the trajectory of sustainable development.

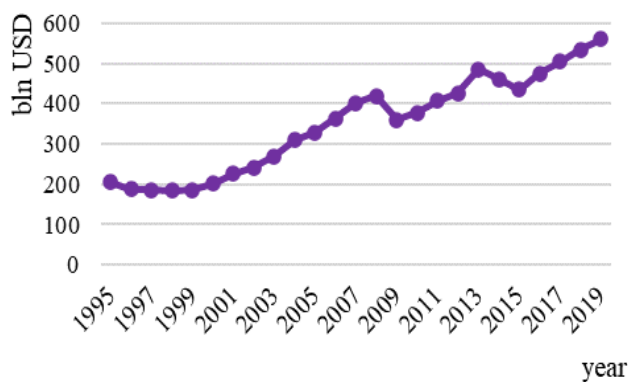

a)

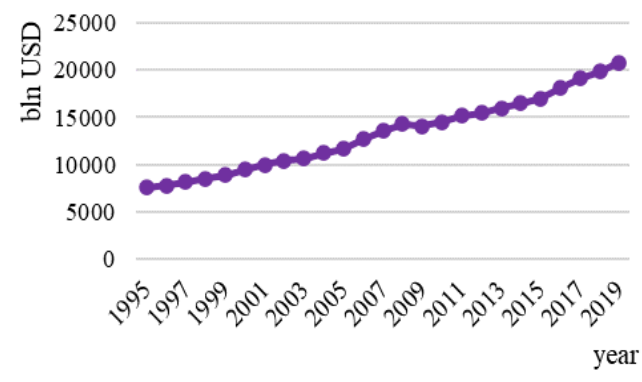

b)

Figure 1. GDP trends of a) Ukraine, b) European Union, current international, bln USD (based on [4])

A Healthy Rate of Growth Is $2 \%$ to $3 \%$ In a healthy economy, growth, unemployment, and inflation are in balance. Most economists agree the ideal GDP growth rate is between $2 \%$ and $3 \%[1]$.

A comparison of employment trends in Ukraine and the EU shows the lack of common trends. The stable growth of the employed population in the EU is interrupted only in the crisis year of 2008 and the following post-crisis years when the EU applied anti-crisis policy aimed at economic recovery. It is in line with the general trend of changes in GDP. On the other hand, there is a relatively stable number of employed people in Ukraine, political than economic factors caused a whose rapid decline in 2013 more. However, the lack of employment growth in subsequent periods is explained by economic reasons, which confirm the data on GDP volume and trends.

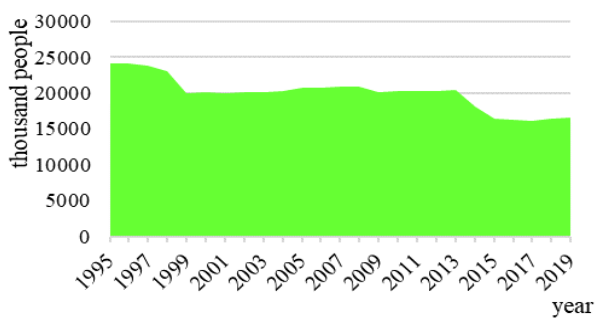

a)

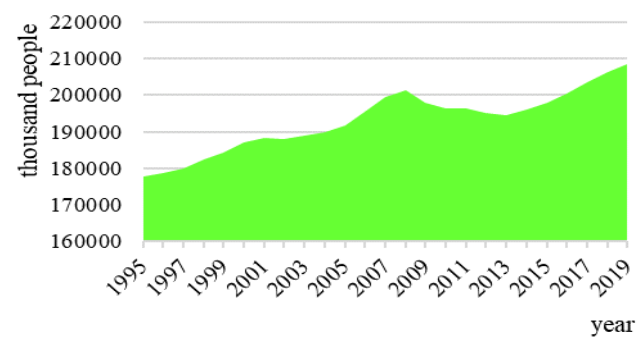

b)

Figure 2. Employment dynamics of a) Ukraine, b) European Union, persons: total economy (National accounts) (NETN) (based on [4]) 
Analysis of fig. 3 confirms the conclusion about different directions of Ukraine and the EU economic development. The inflation rate in the EU during the study period corresponds to building a healthy economy and is characterized by relatively stable indicators.

It provides stable conditions for economic growth and the expected trajectory of development. Instead, the high level of inflation and its periodic peak values indicate problems with forming a balanced economic model in Ukraine. They create an unfavorable investment environment, do not allow to achieve the government's social goals successfully, and hinder life quality growth.

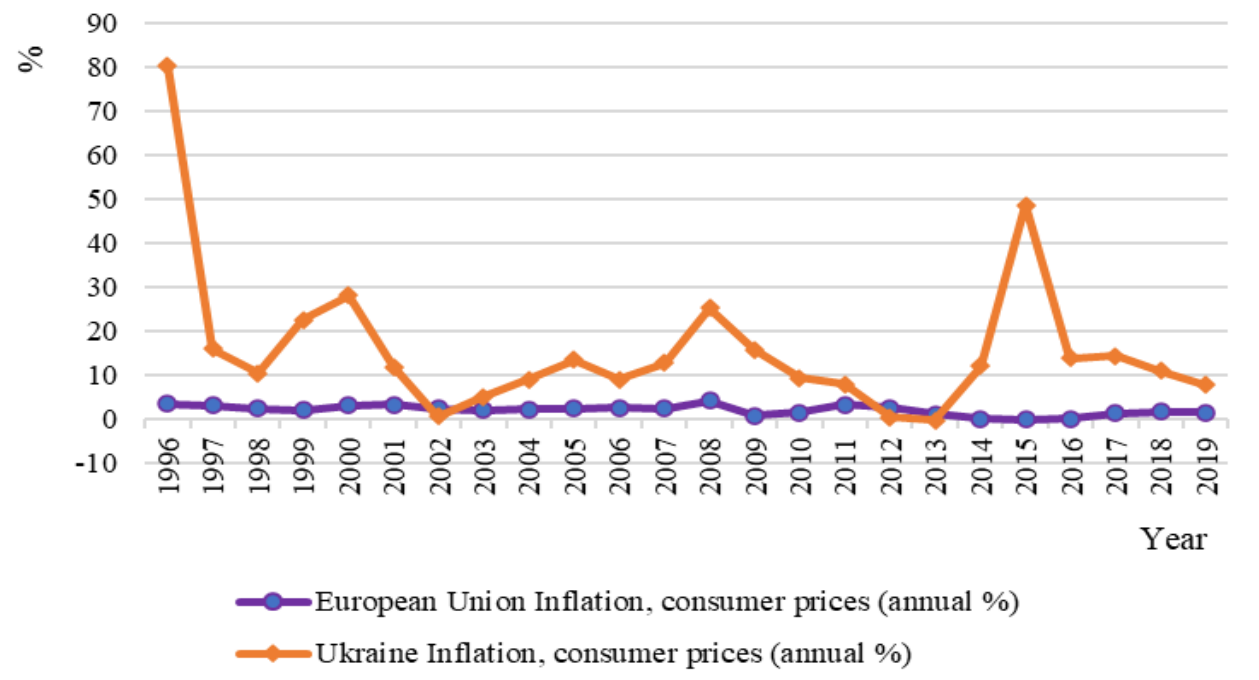

Figure 3. Inflation trends of a) Ukraine, b) European Union (based on [4])

Based on the above facts, it can be concluded that the EU economic model is in line with the trajectory of a healthy economy and contribute to the achievement of sustainable development goals. In contrast, Ukraine has systemic economic problems, without which it is impossible to form a healthy economy.

Conclusions and prospects of further research. Any world economy has three main goals: growth, high employment, price stability. These indicators are the main ones that characterize its health.

Accordingly, the results of the analysis of these indicators confirm the absence of a trajectory of movement towards a healthy economy in Ukraine. Accordingly, a promising area of further research is a detailed study of the essence of a healthy economy, its features for post-Soviet countries, in particular Ukraine, as well as a detailed analysis of the prerequisites and possible options for forming a healthy economy at all levels.

\section{References}

1. Amadeo, K. (2020). What Is the Ideal GDP Growth Rate? Retrieved from https://www.thebalance.com/what-is-the-ideal-gdp-growth-rate-3306017.

2. Bilan, Y., Vasilyeva, T., Lyulyov, O., \& Pimonenko, T. (2019). EU vector of Ukraine development: Linking between macroeconomic stability and social progress. International Journal of Business and Society, 20(2), 433-450. 
Л. Ю. Сагер, Н. С. Летуновська, А. П. Назаренко.

Порівняння України та СС за ключовими показниками здорової економіки

3. Holloway, S. R. (1998). Labor demand, metropolitan context, and male youths' activity strategies. Urban Geography, 19(7), 591-612.

4. International Financial Statistics and data files. World bank. Retrieved from https://data.worldbank.org/indicator/FP.CPI.TOTL.ZG?locations=UA.

5. Letunovska, N., \& Rybina, O. (2020). Comparison and forecast of determinant formation of a healthy region. Efektyvna ekonomika - Effective economy, 4. Retrieved from http://www.economy.nayka.com.ua/?op=1\&z=7773.

6. Marshall, E. (1993). Is environmental technology a key to a healthy economy? Science, 260 (5116), 1886-1888.

7. Nagornyi, Ye. I., Saher, L. Yu., \& Syhyda, L. O. (2017). Comparative analysis of innovation performance in Ukraine and other countries of the world. International Humanitarian University Herald. Economics and Management, 27-2, 23-27.

8. Palienko, M., \& Lyulyov O. (2018). The impact of social factors on macroeconomic stability: empirical evidence for Ukraine and European Union countries. SocioEconomic Challenges, 2(1), 103-116.

9. Philp, T. (2018). Defining a Healthy Economy. Retrieved from https://medium.com /kinblog/defining-a-healthy-economy-2b398c5451af.

10. Śíma, J. (2002). Deflation: An underlying feature of a healthy economy. Finance a Uver. Czech Journal of Economics and Finance, 2002(10), 548-549.

11. Tootelian, D. H., Mikhailitchenko, A., \& Varshney, S. B. (2012). Can producing and marketing healthy foods create a healthy economy? Journal of Food Products Marketing, 18(3), 242-256.

12. Yanushevsky, R., \& Yanushevsky, C. (2015). Stimulus or austerity: Which policy is a road to a healthy economy. Fiscal policy: International aspects, short and long-term challenges and macroeconomic effects, 53-71.

Manuscript received 12 April 2020

Сравнение Украины и ЕС по ключевым показателям здоровой экономики

$$
\begin{gathered}
\text { ЛЮДМИЛА ЮРЬЕВНА САГЕР }{ }^{*}, \\
\text { НАТАЛЬЯ ЕВГЕНЬЕВНА ЛЕТУНОВСКАЯ }{ }^{* *}, \\
\text { АНАСТАСИЯ ПАВЛОВНА НАЗАРЕНКО } \\
\text { *** } \\
\text { * кандидат эКономических наук, доцент кафедры маркетинга } \\
\text { Сумского государственного университета, } \\
\text { ул. Р.-Корсакова, 2, г. Сумы, 40007, Украина, } \\
\text { тел.: 00-380-99-2305820, е-mail: liydmila.sager@gmail.com }
\end{gathered}
$$

** кандидат экономических наук, старший преподаватель кафедры маркетинга

Сумского государственного университета,

ул. Р.-Корсакова, 2, г. Сумы, 40007, Украина,

тел.:00-380-99-1458423,e-mail:sv_pet@ukr.net

*** студентка кафедры маркетинга Сумского государственного университета, ул. Р.-Корсакова, 2, г. Сумы, 40007, Украина, тел.: 00-380-66-3295814

Современные подходы к управлению экономикой базируются на принципах устойчивого развития, обеспечивающего соблюдение баланса между экономическими, экологическими и социальными целями государственной политики, уравновешивание текущих и будущих интересов общества. Механизмом достижения целевых значений индикаторов устойчивого развития является формирование здоровой экономики. Здоровая экономика обеспечивает 
Liudmyla Yu. Saher, Nataliia Ye. Letunovska, Anastasia P. Nazarenko.

Comparison of Ukraine and the EU on Key Indicators of a Healthy Economy

возможности устойчивого роста и минимизирует общественные риски, вызванные экономическими проблемами.

Важность формирования здоровой экономики подтверждается значительным количеством научных исследований по данной тематике в развитых странах мира, в частности Европейском Союзе. Украинский научное сообщество фактически игнорирует данный вопрос. Это свидетельствует о различных подходах к управлению экономикой, определение приоритетных направлений еe развития, согласования экономических и социальных, стратегических и тактических целей.

В работе осуществлен сравнительный анализ ключевых индикаторов, по которым определяется здоровая экономика. К таким индикаторов относятся: ВВП, численность занятого населения и уровень инфляции. Согласно многочисленным исследованиям именно эти показатели являются наиболее показательными при оценке экономической системы, чтобы определить, можно ли считать его здоровым.

В результате исследования было выявлено существенные разногласия по исследуемым показателям между Украиной и Европейским Союзом. На основе использования статистической информации было установлено устойчивую тенденцию к росту ключевых показателей социальноэкономического развития в Европейском Союзе. При этом аналогичные показатели в Украине свидетельствуют об экономической нестабильности, которая имеет значительное негативное влияние на дальнейшее развитие страны и перспективы формирования здоровой экономики. Таким образом, осуществленный анализ позволяет сделать вывод, что экономика Европейского Союза в целом соответствует определению здоровой экономики и создает предпосылки для устойчивого развития Европейского Союза. Зато экономика Украины сосредоточена на решении тактических проблем и в нынешнем состоянии не способна на решение стратегических задач социально-экономического развития.

Ключевые слова: здоровая экономика, сравнительный анализ, показатели развития, ВВП, занятость, инфляция, Европейский Союз

Mechanism of Economic Regulation, 2020, No 3, 134-141

ISSN 1726-8699 (print)

Порівняння України та ЄС за ключовими показниками здорової економіки

$$
\begin{aligned}
& \text { ЛюдМИЛА ЮРІївна САГЕР*, }
\end{aligned}
$$

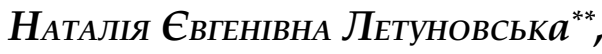

$$
\begin{aligned}
& \text { АНАСТАСІЯ ПАВЛІВНА НАЗАРЕНКО }{ }^{* * *} \\
& \text { Сумського державного університету, } \\
& \text { вул. Р.-Корсакова, 2, м. Суми, 40007, Украӥна, } \\
& \text { тел.: 00-380-99-2305820,e-mail: liydmila.sager@gmail.com }
\end{aligned}
$$

Сучасні підходи до управління економікою грунтуються на принципах сталого розвитку, що забезпечує дотримання балансу між економічними, екологічними та соціальними таргетами 
Л. Ю. Сагер, Н. С. Летуновська, А. П. Назаренко.

Порівняння України та ЄС за ключовими показниками здорової економіки

державної політики, урівноваженням поточних та майбутніх інтересів суспільства. Механізмом досягнення цільових значень індикаторів сталого розвитку є формування здорової економіки. Здорова економіка забезпечує можливості стабільного зростання та мінімізує суспільні ризики, спричинені економічними проблемами.

Важливість формування здорової економіки підтверджується значною кількістю наукових досліджень на дану тематику у розвинених країнах світу, зокрема, Європейському Союзі. Українська наукова спільнота фактично ігнорує дане питання. Це свідчить про різні підходи до управління економікою, визначення пріоритетних напрямків ії розвитку, узгодження економічних та соціальних, стратегічних та тактичних цілей.

У роботі здійснено порівняльний аналіз ключових індикаторів, за якими визначається здорова економіка. До таких індикаторів належать: ВВП, чисельність зайнятого населення та рівень інфляції. Згідно численних досліджень саме ці показники є найбільш показовими під час оцінювання економічної системи, щоб визначити, чи можна вважати її здоровою.

У результаті дослідження було виявлено суттєві розбіжності за досліджуваними показниками між Україною та Європейським Союзом. На основі використання статистичної інформації було встановлено стійку тенденцію до зростання ключових показників соціально-економічного розвитку в Європейському Союзі. Натомість аналогічні показники в Україні свідчать про економічну нестабільність, яка має значний негативний вплив на подальший розвиток країни та перспективи формування здорової економіки. Таким чином, здійснений аналіз дозволяє зробити висновок, що економіка Європейського Союзу загалом відповідає визначенню здорової економіки та створює передумови для сталого розвитку Європейського Союзу. Натомість економіка України зосереджена на вирішенні тактичних проблем та в нинішньому стані не спроможна на вирішення стратегічних завдань соціально-економічного розвитку.

Ключові слова: здорова економіка, порівняльний аналіз, показники розвитку, ВВП, зайнятість, інфляція, Європейський Союз

JEL Codes: E00, O10, O57

Figures: 3; References: 12

Language of the article: English

Лimepamypa

1. Amadeo, K. What Is the Ideal GDP Growth Rate? [Електронний ресурс] / K. Amadeo. - Режим доступу : https://www.thebalance.com/what-is-the-ideal-gdp-growth-rate-3306017.

2. Bilan, $Y$. EU vector of Ukraine development: Linking between macroeconomic stability and social progress / Y. Bilan, T. Vasilyeva, O. Lyulyov, T. Pimonenko // International Journal of Business and Society. 2019. - № 20 (2). - C. 433-450.

3. Holloway, S. R. Labor demand, metropolitan context, and male youths' activity strategies / S. R. Holloway // Urban Geography. 1998. - № 19 (7). - C. 591-612.

4. International Financial Statistics and data files [Електронний pecypc] / World bank. - Режим доступу : https://data.worldbank.org/indicator/FP.CPI.TOTL.ZG?locations=UA.

5. Летуновська, $H$. Порівняння та прогнозування детермінант формування здорового регіону [Електронний ресурс] / Н. Летуновська, О. Рибіна // Ефективна економіка. - № 4. - Режим доступу : http://www.economy.nayka.com.ua/?op=1\&z=7773.

6. Marshall, E. Is environmental technology a key to a healthy economy? / E. Marshall // Science. 1993. - № 260 (5116). - С. 1886-1888.

7. Нагорний, С. I. Порівняльний аналіз показників інноваційної активності України та інших країн світу / Є. І. Нагорний, Л.Ю.Сагер, Л. О. Сигида // Науковий вісник Міжнародного гуманітарного університету. 2017. - № 27-2. - С. 23-27.

8. Palienko, $M$. The impact of social factors on macroeconomic stability: empirical evidence for Ukraine and European Union countries / M. Palienko, O. Lyulyov // SocioEconomic Challenges. 2018. - № 2 (1). - C. 103-116.

9. Philp, T. Defining a Healthy Economy [Електронний pecypc] / T. Philp. - Режим доступу : https://medium.com /kinblog/defining-a-healthy-economy-2b398c5451af. 
Liudmyla Yu. Saher, Nataliia Ye. Letunovska, Anastasia P. Nazarenko. Comparison of Ukraine and the EU on Key Indicators of a Healthy Economy

10. Šíma, J. Deflation: An underlying feature of a healthy economy. Finance a Uver / J. Šíma // Czech Journal of Economics and Finance. 2002. - № 10. - C. 548-549.

11. Tootelian, $D . H$. Can producing and marketing healthy foods create a healthy economy? / D. H. Tootelian, A. Mikhailitchenko, S. B. Varshney // Journal of Food Products Marketing. 2012. № 18 (3). - C. 242-256.

12. Yanushevsky, R. (2015). Stimulus or austerity: Which policy is a road to a healthy economy / R. Yanushevsky, C. Yanushevsky // Fiscal policy: International aspects, short and long-term challenges and macroeconomic effects. - C. 53-71. 